\title{
PENGEMBANGAN PERANGKAT PEMBELAJARAN PENDIDIKAN KEAKSARAAN DASAR BERBASIS KEARIFAN LOKAL PADA KOMUNITAS ADAT TERPENCIL (KAT) SUKU DAYAK MERATUS
}

\author{
Nunung Nurazizah \\ e-mail: nunungnurazizah@yahoo.co.id \\ BP-PAUD dan Dikmas Kalimantan Selatan \\ JI. Ambulung, Kalimantan Selatan 70714
}

\begin{abstract}
Abstrak: Perangkat pembelajaran yang terdiri dari bahan ajar, silabus dan Rencana Pelaksanaan Pembelajaran (RPP), panduan pembelajaran, panduan penilaian pendidikan keaksaraan dasar pada Komunitas Adat Terpencil (KAT) suku Dayak Meratus disusun untuk kelengkapan pembelajaran pendidikan keaksaraan dasar dalam mencapai standar kompetensi lulusan peserta didik pendidikan keaksaraan dasar sesuai Permendikbud No. 86 tahun 2014. Penyusunan perangkat pembelajaran menggunakan metode penelitian dan pengembangan (research and development). Uji coba dalam penelitian pengembangan ini dilakukan di PKBM Belimbing Kabupaten Hulu Sungai Selatan (sebagai kelompok treatment) dan SPNF SKB Kabupaten Balangan (sebagai kelompok control) dari Agustus sampai Oktober 2017. Uji validitas konseptual produk perangkat pembelajaran pendidikan keaksaraan dasar diperoleh dengan perhitungan rata-rata (mean) $82,8 \%$, tingkat validitas sangat tinggi. Uji kemenarikan dan keterbacaan konseptual diperoleh dengan perhitungan rata-rata (mean) $76,4 \%$, tingkat kemenarikan dalam kategori tinggi. Dampak dari penerapan perangkat pembelajaran agar peserta didik dapat memiliki literasi dalam segala bidang kehidupan.
\end{abstract}

Kata-kata kunci: perangkat pembelajaran, keaksaraan dasar, suku Dayak Meratus

\section{THE DEVELOPMENT OF THE BASIC LITERACY EDUCATIONAL LEARNING INSTRUMENTS BASED ON THE LOCAL WISDOM OF DAYAK MERATUS REMOTE COMMUNITY}

\begin{abstract}
The learning instruments that consisted of the teaching materials, syllabuses, lesson plans $(R P P)$, learning guides, and evaluation guides of basic literacy educational learning at the remote indigenous community of Dayak Meratus tribe were composed for the completion of the basic literacy educational learning instruments in order to achieve course learning outcome of the basic literacy education in accordance to the regulation of the minister of education and culture no.86 2014. The research and development method was employed in developing the learning instruments. The tryouts in this research and development were conducted in PKBM Belimbing of Hulu Sungai Selatan (as the experiment group) and SPNF SKB Balangan (as the control group) from August to October 2017. The basic literacy educational learning instruments conceptual product validity test was obtained with the mean calculation of $82.8 \%$ which meant that validity level was very high. The attractiveness and conceptual literacy test was obtained with the mean calculation of $76,4 \%$ which meant that the attractiveness level was in the high category. The effect of the learning instruments'implementation was intended that the learners could get the literacy in all aspects of their life.
\end{abstract}

Keywords: learning instruments, basic literacy educational learning literacy, Dayak Meratus language

\section{PENDAHULUAN}

Agenda pendidikan tahun 2030, komitmen dunia mendukung kesempatan belajar sepanjang hayat untuk semua, pada seluruh lingkungan dan tingkat pendidikan (Ella, 2016). Sejalan dengan agenda tersebut, layanan pendidikan keaksaraan memegang peran strategis dan penting. Hal ini karena pada tahun 2016 secara nasional masih terdapat sebesar 2,07\% atau 3,9 juta orang buta 
aksara usia 15-59 tahun dan dua pertiga diantaranya adalah perempuan (Susenas BPS, 2016). Program layanan pendidikan keaksaraan ini diharapkan dapat menurunkan angka buta aksara di Indonesia.

Di Kabupaten Hulu Sungai Selatan, berdasarkan data buta aksara tahun 2010, angka buta aksara untuk usia 15 tahun ke atas mencapai 144.500 orang dan mengalami penurunan signifikan tahun 2016 sejumlah 12.800 orang dan pada tahun 2017 diharapkan tinggal 31.000 orang (Kalimantan Pos, 2016), sedangkan jumlah buta aksara di Kabupaten Balangan tahun 2015 usia 15-59 tahun berjumlah 1.483 dengan rincian laki-laki 678 orang dan perempuan 805 orang, yang sudah terlayani pendidikan keaksaraan dasar pada tahun 2016 berjumlah 1.050 dengan rincian laki-laki 180 orang dan perempuan 870 orang (Dinas Pendidikan Kabupaten Balangan, 2017).

Jumlah penduduk di Kabupaten Hulu Sungai Selatan berjumlah 256.075 jiwa, sedangkan buta aksara di Kabupaten Hulu Sungai Selatan pada tahun 2010 sebanyak 9.471 orang dan pada tahun 2016 yang buta aksara sebanyak 1973 orang (Dinas Pendidikan Kabupaten Hulu Sungai Selatan, 2016). Jumlah Penduduk pada Kecamatan Loksado pada tahun 2013 berjumlah 9.575 jiwa (Dinas Kependudukan dan Catatan Sipil Kab. Hulu Sungai Selatan, 2013), sedangkan data kependudukan di Desa Loklahung Kecamatan Loksado Kabupaten Hulu Sungai Selatan dapat dilihat pada tabel 1.

Tabel 1

Data Kependudukan Desa Loklahung Kecamatan Loksado Kabupaten Hulu Sungai Selatan

\begin{tabular}{cccccc}
\hline \multirow{2}{*}{ No. } & RT & \multicolumn{3}{c}{ Jumlah Penduduk } & \multirow{2}{*}{ Jumlah } \\
\cline { 3 - 5 } & & LK & PR & LK+PR & KK \\
\hline 1 & RT. 01 & 108 & 89 & 197 & 47 \\
2 & RT. 02 & 91 & 62 & 153 & 25 \\
3 & RT. 03 & 56 & 47 & 103 & 20 \\
\hline \multirow{2}{*}{ No. } & RT & \multicolumn{3}{c}{ Jumlah Penduduk } & Jumlah \\
\cline { 3 - 5 } & & LK & PR & LK+PR & KK \\
\hline 4 & RT.04 & 37 & 33 & 70 & 18 \\
\hline \multicolumn{2}{c}{ Jumlah } & 292 & 231 & 523 & 110 \\
\hline
\end{tabular}

Sementara itu, untuk agama yang dianut masyarakat Desa Loklahung tempat penyelenggaraan Pendidikan Keaksaraan Dasar Komunitas Adat Terpencil (KD-KAT) yaitu Agama Islam 10 orang, Kristen 10 orang, dan Kaharingan 503 orang. Kabupaten Balangan dan Kabupaten
Hulu Sungai Selatan merupakan kabupaten di Provinsi Kalimantan Selatan yang terdapat komunitas Dayak, sedangkan suku Dayak Meratus banyak bertempat tinggal di Kabupaten Hulu Sungai Selatan, Kecamatan Loksado.

Penyelenggaraan Pendidikan Keaksaraan Dasar hendaknya sesuai dengan Peraturan Menteri Pendidikan dan Kebudayaan Republik Indonesia Nomor 86 Tahun 2014 tentang Penyelenggaraan Pendidikan Keaksaraan Dasar. Berdasarkan wawancara dengan beberapa pengelola program pendidikan keaksaraan bahwa pengelola mengalami kesulitan dalam melaksanakan program pendidikan keaksaraan dasar yang mengacu pada Peraturan Menteri Pendidikan dan Kebudayaan Republik Indonesia Nomor 86 Tahun 2014. Oleh karena itu, perlu upaya untuk memudahkan pengelola program dalam menyelenggarakan pendidikan keaksaraan dasar yang sesuai dengan kurikulum pendidikan keaksaraan dasar.

Salah satu pendukung agar pelaksanaan pendidikan keaksaraan dasar sesuai dengan kurikulum adalah ketersediaan bahan ajar, silabus dan RPP, panduan pembelajaran, panduan penilaian yang mengacu pada kurikulum pendidikan keaksaraan dasar. Dengan adanya bahan ajar, silabus dan RPP, panduan pembelajaran, panduan penilaian pendidikan keaksaraan dasar diharapkan mampu memberikan pengetahuan, keterampilan sesuai dengan standar kompetensi yang diharapkan. Hasil studi kelayakan menemukan masih banyaknya masyarakat yang buta aksara di Kabupaten Hulu Sungai Selatan yang berjumlah 17.675 jiwa dengan realisasi penuntasan buta aksara sampai tahun 2013 berjumlah 7.202 jiwa sehingga masih terdapat 10.473 jiwa penduduk buta aksara (Dinas Pendidikan Kab. Hulu Sungai Selatan, 2013).

Masyarakat yang buta aksara perlu layanan program pendidikan keaksaraan, sehingga dapat membaca, menulis, berhitung, dan berdaya dalam kehidupan sehari-hari. Diantara kendala dalam pembelajaran adalah masalah ketersediaan bahan ajar dimana bahan ajar yang tersedia adalah bahan ajar terbitan tahun 2009, sehingga kurang sesuai dengan kompetensi keaksaraan yang mengacu pada Permendikbud No.86 Tahun 2014. Sementara di sisi lain, instrumen penilaian sudah mengunakan kurikulum keaksaraan dasar yang mengacu pada Kurikulum 2013. Hal ini menyebabkan kurang sinkron antara bahan ajar yang tersedia dan penilaian akhir 
program. Oleh karena itu, dipandang perlu untuk menyusun bahan ajar KD-KAT suku Dayak Meratus, apalagi dengan kondisi sosial budaya komunitas yang khusus tersebut.

Pengembangan perangkat pembelajaran pendidikan keaksaraan dasar berbasis kearifan lokal pada KAT suku Dayak Meratus diharapkan dapat mendukung kegiatan pembelajaran yang berbasis lokal dan berupa konteks lokal sebagai upaya peningkatan keberaksaraan warga masyarakat sesuai kebutuhan, kondisi, permasalahan, budaya, dan karakteristik masyarakat sasaran program pendidikan KD-KAT. Hal ini sesuai dengan isi Permendikbud No.86 tahun 2014 tentang Penyelenggaraan Pendidikan Keaksaraan Dasar yaitu membantu menumbuhkan kebiasaan pada peserta didik untuk mencari dan mempergunakan media baca tulis hitung sendiri dari berbagai sumber di sekitar lingkungan tempat peserta didik berdomisili. Oleh karena bahan ajar yang dikembangkan untuk suku Dayak Meratus, maka bahan ajar ditulis dalam dua bahasa yaitu bahasa Indonesia dan bahasa Dayak Meratus. Diharapkan dengan pemberdayaan melalui pembelajaran yang berbasis kearifan lokal, akan meningkatkan kualitas dan taraf hidup Suku Dayak Meratus.

Pendidikan keaksaraan dasar adalah program yang bertujuan untuk pemberantasan buta huruf dan buta pendidikan dasar agar seseorang melek aksara atau memiliki literasi dalam segala bidang kehidupan, untuk menghadapi pesatnya perubahan sosial dan perkembangan masyarakat (Lampiran Peraturan Menteri Pendidikan dan Kebudayaan Nomor 86 Tahun 2014 tentang pedoman Penyelenggaraan Pendidikan Keaksaraan Dasar).

Mengacu kepada Permendikbud Nomor 86 Tahun 2014 tentang Penyelenggaraan Pendidikan Keaksaraan Dasar yang meliputi ranah sikap, pengetahuan, dan keterampilan, maka capaian hasil belajar bagi lulusan pendidikan keaksaraan dasar meliputi (1) ranah sikap, memiliki perilaku dan etika yang mencerminkan sikap orang beriman dan bertanggung jawab dalam berinteraksi dengan lingkungan keluarga, masyarakat, dan alam dalam kehidupan sehari-hari; (2) ranah pengetahuan, menguasai pengetahuan faktual, tentang cara berkomunikasi melalui bahasa Indonesia dan berhitung dalam hidup bermasyarakat; dan (3) ranah keterampilan, memiliki kemampuan menggunakan bahasa Indonesia dan keterampilan berhitung untuk melakukan aktivitas sehari-hari dalam kehidupan keluarga dan masyarakat.

Program pendidikan keaksaraan dasar ini dilaksanakan dengan alokasi waktu minimal 114 jam pelajaran @60 menit yang terdiri atas keterampilan membaca dan menulis sebanyak 80 jam dan keterampilan berhitung sebanyak 34 jam. Menurut Permendikbud Nomor 86 Tahun 2014 tentang Penyelenggaraan Pendidikan Keaksaraan Dasar, kompetensi dasar pendidikan keaksaraan dasar pada dimensi sikap meliputi (1) mampu melakukan ibadah sesuai dengan agama dan kepercayaan masing-masing; (2) mampu menunjukkan sikap santun dalam berkomunikasi dan taat pada aturan yang disepakati; dan (3) mampu menunjukkan sikap jujur dalam berkomunikasi dan berhitung pada kehidupan sehari-hari.

Sementara itu, kompetensi dasar pendidikan keaksaraan dasar pada dimensi pengetahuan meliputi (1) menguasai teknik membaca; (2) mengenal teks personal tentang identitas diri; (3) mengenal teks deskripsi minimal 3 (tiga) kalimat sederhana yang berkaitan dengan kehidupan seharihari; (4) mengenal teks informasi sederhana dalam bentuk poster yang berkaitan dengan kehidupan sehari-hari; (5) mengenal teks narasi pendek minimal 3 (tiga) kalimat sederhana yang berkaitan dengan kehidupan sehari-hari; (6) mengenal teks petunjuk/ arahan minimal 3 (tiga) kalimat yang berkaitan dengan kehidupan sehari-hari; (7) mengenal bilangan (1-1000), uang, dan operasinya dalam kehidupan sehari-hari; dan (8) mengenal dan membaca satuan panjang, berat, isi, dan waktu yang biasa digunakan dalam kehidupan sehari-hari (Permendikbud Nomor 86 Tahun 2014).

Kompetensi dasar pendidikan keaksaraan dasar pada dimensi keterampilan meliputi (1) membaca suku kata dan kata yang terdiri atas huruf vokal dan konsonan berkaitan dengan kehidupan sehari-hari; (2) membaca lancar teks minimal 3 (tiga) kalimat sederhana dan memahami isinya; (3) menulis kata dan kalimat sederhana yang berkaitan dengan kehidupan sehari hari; (4) menulis teks personal tentang identitas diri; (5) menulis teks deskripsi tentang penggambaran sebuah objek (benda, hewan, tumbuhan, atau orang) dalam bahasa Indonesia minimal tiga kalimat sederhana berkaitan dengan kehidupan sehari-hari; (6) menulis teks informasi dalam bentuk poster menggunakan bahasa Indonesia; (7) menulis teks narasi minimal tiga 
kalimat yang di dalamnya terdapat kalimat majemuk berdasarkan gambar tunggal atau gambar seri; (8) menulis teks petunjuk/arahan tentang kehidupan sehari-hari minimal tiga kalimat dengan atau tanpa bantuan gambar; (9) melakukan dan menggunakan operasi penjumlahan, pengurangan, perkalian, dan pembagian bilangan sampai dua angka dalam kehidupan sehari-hari; dan (10) mengukur dan menggunakan satuan ukuran panjang, jarak, berat, dan waktu yang biasa digunakan dalam kehidupan sehari-hari serta menafsirkan hasil pengukuran (Permendikbud No. 86 Tahun 2014).

Bahan ajar adalah segala bentuk bahan yang digunakan untuk membantu tutor dalam melaksanakan kegiatan pembelajaran, sehingga memungkinkan peserta didik untuk belajar karena sesuai dengan situasi dan kondisi peserta didik. Dalam pengertian lain bahan ajar dapat dimaknai sebagai benda-benda fisik yang digunakan dalam sebuah pembelajaran yang memengaruhi kegiatan pembelajaran. Bahan ajar juga dimaknai sebagai seperangkat materi/substansi pelajaran (teaching material) yang disusun secara sistematis, menampilkan sosok utuh dari kompetensi yang akan dikuasai peserta didik dalam kegiatan pembelajaran.

Bahan ajar merupakan media agar peserta didik dapat mengalami, menghayati, mengolah, mengungkapkan, menyimpulkan, dan menerapkan materi-materi yang telah diajarkan dalam kehidupan sehari-hari, juga segala bentuk bahan yang digunakan untuk membantu tutor dalam melaksanakan kegiatan pembelajaran (Heinic dalam Arsyad, 2003). Bahan ajar dapat mendukung proses pembelajaran pada program pendidikan keaksaraan dengan syarat sebagai berikut (1) meningkatkan motivasi belajar peserta didik; (2) sesuai dengan lingkungan dan kehidupan peserta didik; dan (3) langsung diterapkan dalam kehidupan sehari-hari peserta didik.

Secara umum jenis bahan ajar biasanya terdiri atas handout, buku, modul, dan belajar terprogram. Dalam pendidikan KD-KAT ini yang dimaksud dengan bahan ajar adalah isi pesan yang menjadi materi belajar berupa tulisan atau gambar yang dituangkan dalam bentuk buku, poster, daN leaflet yang digunakan oleh peserta didik. Bentuk bahan belajar pendidikan KD-KAT terdiri atas (1) tulisan seperti buku, brosur, dan leaflet; (2) gambar, seperti poster, film, dan video; dan (3) alat peraga, yaitu alat dan bahan praktik.

Kegunaan bahan ajar dalam pendidikan keaksaraan dasar adalah (1) sebagai alat bantu bagi tutor untuk membelajarkan materi pendidikan keaksaraan dasar yang disesuaikan dengan standar kompetensi dan kompetensi dasar sesuai Permendikbud No. 86 tahun 2014; dan (2) sebagai alat bantu bagi peserta didik untuk mencapai standar kompetensi dan kompetensi dasar yang telah dipetakan pada tiap-tiap bahan ajar.

Bahan ajar pendidikan keaksaraan dasar dikembangkan dengan maksud (1) kesesuaian bahan ajar dengan kondisi lingkungan dan sosial budaya peserta didik; (2) meningkatkan kemampuan keberaksaraan peserta didik; (3) memberikan kemudahan peserta didik dalam memahami informasi karena materi sesuai dengan kehidupan mereka senari-hari; (4) mengembangkan kesadaran kritis peserta didik tentang kondisi lingkungan sesuai dengan materi di bahan ajar; (5) membentuk sikap mental rasional peserta didik terhadap materi pembelajaran; (6) berorientasi pada nilai, sikap mental, dan keterampilan yang diinginkan; dan (7) memberikan hiburan pada peserta didik khususnya pada bahan ajar yang berupa foto atau video (Subdit Pendidikan Keaksaraan, 2005).

Bahan ajar pendidikan keaksaraan dasar dalam penelitian ini adalah media yang digunakan oleh tutor dan peserta didik dalam pembelajaran keaksaran dasar yang disesuaikan dengan budaya lokal masyarakat adat terpencil dengan menggunakan pendekatan bahasa ibu (bahasa Dayak Meratus) dalam bentuk buku, brosur, leaflet, foto, dan video kegiatan pembelajaran peserta didik.

Masing-masing suku memiliki kearifan lokal sendiri. Kearifan lokal merupakan sesuatu yang berkaitan secara khusus atau ciri khas dari budaya tertentu (budaya lokal) dan mencerminkan cara hidup suatu masyarakat tertentu (masyarakat lokal). Dengan kata lain, kearifan lokal ada pada budaya lokal (local culture). Budaya lokal disebut juga budaya daerah. Menurut Peraturan Menteri Dalam Negeri Nomor 39 Tahun 2007 Pasal 1 mendefinisikan budaya daerah sebagai suatu sistem nilai yang dianut oleh komunitas atau kelompok masyarakat tertentu di daerah, yang diyakini akan dapat memenuhi harapan-harapan warga masyarakatnya dan di dalamnya terdapat nilai-nilai, sikap tata cara masyarakat yang diyakini dapat memenuhi kehidupan warga masyarakatnya.

Dengan demikian dapat disimpulkan bahwa kearifan lokal adalah pengetahuan, keterampilan, 
dan sikap dalam menghadapi lingkungan hidup yang dikembangkan oleh para leluhur agar dapat menyesuaikan diri dengan kondisi lingkungan hidup sekitar mereka, yang menjadikan pengetahuan dan sikap itu sebagai bagian dari budaya dan selanjutnya dapat memperkenalkan serta meneruskannya ke generasi berikutnya. Beberapa bentuk pengetahuan tradisional itu muncul lewat cerita-cerita, legendalegenda, nyanyian-nyanyian, ritual-ritual, dan juga aturan atau hukum setempat. Pada suku Dayak Meratus, ritual diadakan pada saat akan memulai menanam padi dan pada saat panen padi sebagai rasa syukur terhadap alam dan Yang Maha Kuasa.

Kearifan lokal dayak adalah nilai-nilai budaya, ritual keagamaan pada masyarakat suku dayak. Dayak sendiri adalah nama yang oleh penduduk pesisir Pulau Borneo diberi kepada penghuni pedalaman yang mendiami pulau. Di Kalimantan Selatan ada suku Dayak Meratus di Kabupaten Hulu Sungai Selatan dan suku Dayak Dusun Balangan di Kabupaten Balangan yang termasuk pada golongan suku Dayak Ngaju. Kearifan lokal Dayak mencakup jenis mata pencaharian, upacara-upacara adat, tarian adat, bangunan adat seperti balai adat sebagai tempat upacara adat, pertemuan warga, dan tempat menyimpan benda tradisional yang digunakan untuk upacara adat (Syahriansyah, dkk, 2011). Balai adat yang digunakan dalam penelitian ini yaitu Balai adat Malaris, Balai Manutui, Balai Mawak, dan Balai Haratai yang semuanya berada di Kecamatan Loksado Kabupaten Hulu Sungai Selatan.

Bahasa sehari-hari yang digunakan orang Dayak terdiri dari berbagai bahasa, karena pada suku Dayak ada beragam suku atau komunitas adat. Bahasa yang banyak digunakan oleh orang Dayak adalah bahasa Dayak Ngaju. Dalam tata bahasa Dayak Ngaju, menyatakan Dayak Ngaju dari kata Dayak yang berarti sedikit atau kecil dan Ngaju berarti udik atau hulu. Dengan demikian diduga asal muasal penutur bahasa Dayak Ngaju berdiam di daerah hulu sungai terutama Sungai Kapuas, Katingan, Sungai Barito, Seruyan, Mentaya, dan Kahayan.

Bahasa Melayu Bukit atau bahasa Dayak Meratus merupakan salah satu bahasa dalam rumpun bahasa Austronesia yang dituturkan oleh suku Dayak Bukit yang mendiami daerah sepanjang pegunungan Meratus di Kalimantan Selatan. Bahasa Melayu Bukit ini merupakan bentuk arkhais (bahasa terdahulu) dari bahasa Banjar sebelum bahasa
Banjar sendiri mendapatkan pengaruh dari bahasa Jawa. Misalnya adanya kosakata ayying (air) yang sudah tidak ada lagi dalam bahasa Banjar dan digantikan dengan kata pinjaman banyu dari bahasa Jawa, sedangkan bahasa Dayak Meratus sudah banyak dipengaruhi oleh bahasa Banjar, sehingga kosa kata dalam bahasa Dayak Meratus tidak begitu berbeda dengan bahasa Banjar yang merupakan bahasa suku Banjar di Kalimantan Selatan.

Dalam sistem kepercayaan yang dianut oleh masyarakat suku Dayak Meratus, terdapat empat agama yaitu Islam, Kristen, Katolik, dan agama pribumi yaitu Kaharingan. Agama Kaharingan tetap menjadi agama mayoritas yang sampai saat ini masih dianut dan dihayati oleh suku Dayak Meratus. Agama Kaharingan atau disebut pula dengan Hindu Kaharingan merupakan kepercayaan tradisional suku Dayak. Secara etimologi, Kaharingan berarti tumbuh dan hidup. Agama Kaharingan juga memiliki berapa kitab suci diantaranya Panuturan, Talatah Basrah (kumpulan doa-doa), dan Tara (kitab petunjuk tata cara meminta pertolongan kepada Tuhan dengan upacara menabur beras), sehingga dalam kartu tanda penduduk, identitas keagamaan dimasukkan dalam agama Hindu. Tempat ibadah dalam agama Kaharingan disebut Balai Basrah atau Balai Kaharingan yang merupakan tempat utama bagi umat Hindu Kaharingan melakukan ibadah sembahyang, juga untuk melakukan ritual keagamaan seperti aruh ganal pada saat memulai dan panen padi.

Sistem mata pencaharian suku Dayak secara keseluruhan dapat dikategorikan dalam tiga hal yaitu bertani atau berladang, berburu dan menangkap ikan, serta pegawai dan karyawan. Namun, sistem mata pencaharian utama sekaligus paling utama bagi suku Dayak adalah bertani dan berburu.Untuk suku Dayak Meratus tempat peserta didik program KD-KAT, memiliki mata pencaharian berladang (kayu manis, buah kemiri, dan pohon karet) dan menanam padi.

Tradisi atau kebiasaan (Latin: traditio, "diteruskan") adalah sesuatu yang telah dilakukan sejak lama dan menjadi bagian dari kehidupan masyarakat Dayak Meratus. Ritual adalah serangkaian kegiatan keagamaan yang dilaksanakan pada waktu yang telah ditentukan oleh para ketua adat dan pendeta/balian. Salah satu ritual keagamaan yang menjadi tradisi masyarakat adat Dayak di Kalimantan Selatan yang sangat terkenal 
bahkan menjadi tujuan wisata adalah aruh adat. Aruh adat diartikan sebagai upacara adat, ada berupa aruh ganal. Aruh ganal dapat dilaksanakan sampai 7 hari 7 malam. Bagi masyarakat adat suku Dayak, aruh ganal adalah sebagai rasa syukur atas panen yang sudah mereka laksanakan dan sebagai awal untuk memulai kembali bercocok tanam. Dalam aruh ganal terdapat serangkaian kegiatan mulai dari taritarian sampai dengan acara persembahan.

Sistem kekerabatan adalah gabungan patrilineal dan matrilineal atau sistem kekerabatan bilateral. Bagi suku Dayak tidak ada perbedaan dalam pembagian warisan bagi anak laki-laki dan perempuan, yang berbeda di wilayah pembagian tugas saja. Suku Dayak biasa tinggal satu rumah (balai) bagi mereka yang belum memiliki rumah. Jika sudah mampu membuat rumah mereka akan keluar dari balai tersebut (Faidi, 2015). Sistem perjodohan sudah semakin lentur karena setiap anak diberikan kebebasan dalam menentukan teman hidupnya. Dalam hal ini jenis perkawinan yang dilarang adalah perkawinan dengan golongan keluarga sendiri, yaitu saudara sekandung (incest) dan saudara sepupu dari garis keturunan ayah (patriparalel cousin).

Kondisi geografis suku Dayak Meratus berada di bentangan pegunungan Meratus yang terletak antara 115035'55" sampai 115047'43" Bujur timur dan 02025'32" sampai 02035'26" Lintang selatan. Jarak desa ke ibukota kecamatan $35 \mathrm{~km}$, jarak desa ke ibukota kabupaten $48 \mathrm{~km}$, dan jarak desa ke ibukota provinsi $231 \mathrm{~km}$. Oleh karena itu, dikenal dengan Dayak Meratus, karena berada di wilayah bentangan pegunungan maka kondisi geografisnya berupa pegunungan, perbukitan yang naik turun, dan terdapat aliran sungai.

\section{METODE PENELITIAN}

Penelitian ini bertujuan untuk mengembangkan perangkat pembelajaran pada pendidikan keaksaraan dasar dengan sasaran komunitas adat suku Dayak Meratus. Sesuai dengan tujuan penelitian ini, yaitu agar bahan ajar yang dikembangkan dapat digunakan oleh peserta didik keaksaraan dasar pada suku Dayak Meratus, maka metode penelitian yang digunakan adalah metode penelitian pengembangan (reseach and development). Metode penelitian dan pengembangan/research and development adalah metode penelitian yang digunakan untuk menghasilkan produk tertentu dan memiliki inovasi dengan menguji keefektifan produk. Tujuan pengembangan model ini adalah untuk menghasilkan produk berupa perangkat pembelajaran yang terdiri dari bahan ajar, silabus dan RPP, panduan pembelajaran, panduan penilaian yang berkontek lokal suku Dayak Meratus, maka metode yang digunakan adalah metode penelitian pengembangan yang mengacu pada yang dikembangkan oleh Borg and Gall.

Prosedur pengembangan disesuaikan dengan kebutuhan secara konseptual (Borg dan Gall, 1979), dalam penelitian ini mengikuti langkah berikut (1) identifikasi kebutuhan pengembangan, dilakukan melalui studi lapangan/eksplorasi sebagai studi empiris dan studi kepustakaan; (2) pengembangan model konseptual, meliputi (a) penyusunan draft model pengembangan perangkat pembelajaran; (b) diskusi terpumpun draft model, yaitu kegiatan seminar draft model agar mendapatkan masukan dari ahli dan praktisi yang mengikuti diskusi terpumpun; (c) uji coba konseptual, dilakukan dengan melibatkan ahli, praktisi, dan peserta didik pendidikan keaksaraan dasar sesuai dengan model yang sedang dikembangkan serta kepada calon pengguna model (tutor program pendidikan keaksaraan dasar dan peserta didik) dengan menggunakan instrumen validasi yang disusun oleh peneliti; dan (d) review model konseptual, dilakukan dengan melibatkan tim pengembang, akademisi/pakar/praktisi yang membidangi untuk memperoleh perbaikan model konseptual; (3) uji coba model operasional, tahap ini digunakan untuk mengukur tingkat keefektifan, keterlaksanaan atau kepraktisan, dan kemenarikan. Adapun langkah ujicoba meliputi (a) menetapkan rancangan uji coba pada dua kelompok sasaran, yaitu kelompok eksperimen dan kelompok kontrol yang keduanya berada di wilayah/ kabupaten yang berbeda. Kelompok eksperimen pada Kabupaten Hulu Sungai Selatan dan kelompok kontrol pada Kabupaten Balangan, dengan jumlah kelompok treatment 10 kelompok masing-masing 10 warga belajar; (b) menyiapkan model dan perangkat pendukung model yang akan diujicobakan; (c) melaksanakan orientasi calon sasaran uji coba pengembangan model kepada penyelenggara program dan pendidik 
yang akan melaksanakan pembelajaran, sehingga terdapat persamaan persepsi terhadap model yang akan diujicobakan; (d) melaksanakan uji coba, observasi, dan mencatat kegiatan pembelajaran selama pelaksanaan uji coba juga dilakukan; (e) analisis data dengan menggunakan t-test untuk uji keefektifan, rata-rata/mean untuk uji kemenarikan dan keterlaksanaan; serta (f) diskusi terpumpun hasil uji coba pengembangan model, untuk merevisi model dari hasil analisis dan masukan-masukan dari penyelenggara sehingga menjadi naskah model final yang siap dibakukan dan selanjutnya digandakan; dan (4) pembakuan model hasil pengembangan, yang dilakukan melalui kegiatan diskusi dengan melibatkan unsur Direktorat Pendidikan Masyarakat untuk memperoleh masukan perbaikan dan pengesahan/validasi model.

Uji coba dalam penelitian pengembangan ini dilakukan di PKBM Belimbing Kabupaten Hulu Sungai Selatan (sebagai kelompok treatment) dan SPNF SKB Kabupaten Balangan (sebagai kelompok control), mulai dari Agustus sampai Oktober 2017. Subjek uji coba dalam penelitian ini adalah tutor sebanyak 20 orang dan peserta didik sebanyak 100 orang peserta didik pendidikan keaksaraan dasar. Instrumen yang digunakan dalam penelitian pengembangan ini berupa tes, wawancara, observasi, kuesioner, dan dokumentasi.

Teknik dokumentasi digunakan saat tahap studi pendahuluan. Teknik kuesioner digunakan saat uji coba konseptual model untuk mengetahui tingkat keterbacaan dan kemenarikan naskah model yang selanjutnya dianalisis menggunakan rata-rata (mean). Teknik tes digunakan untuk mengukur keberhasilan pembelajaran menggunakan naskah model pengembangan yang selanjutnya dianalisis menggunakan $t$-test untuk mengetahui tingkat efektivitas produk. Teknik wawancara untuk memperoleh informai mendalam terkait penggunaan produk yang dikembangkan, dan observasi untuk melihat keterpakaian model dan dampak model yang selanjutnya dianalisis secara induktif kualitatif dengan rata-rata/mean untuk uji kemenarikan dan keterlaksanaan.

Skema pengembangan perangkat pembelajaran pendidikan KD-KAT suku Dayak Meratus lebih jelasnya digambarkan pada gambar 1 .

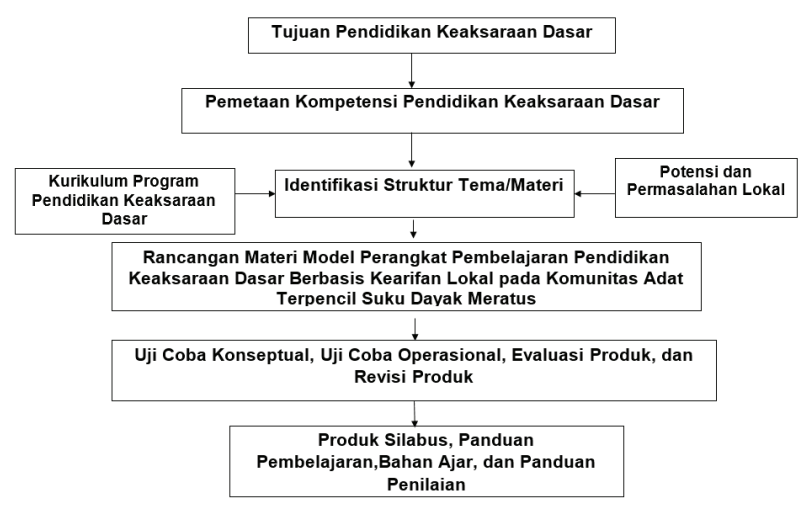

Gambar 1. Langkah pengembangan perangkat pembelajaran

\section{HASIL DAN PEMBAHASAN}

\section{Hasil}

Kompetensi lulusan pendidikan keaksaraan dasar merupakan kualifikasi kemampuan lulusan yang mencakup sikap, pengetahuan, dan keterampilan yang terdiri atas (1) memiliki perilaku dan etika yang mencerminkan sikap orang beriman dan bertanggung jawab dalam berinteraksi dengan lingkungan keluarga, masyarakat, dan alam dalam kehidupan sehari-hari; (2) menguasai pengetahuan faktual tentang cara berkomunikasi melalui bahasa Indonesia dan berhitung untuk melakukan aktivitas sehari-hari dalam kehidupan keluarga dan bermasyarakat; serta (3) mampu menggunakan bahasa Indonesia dan keterampilan berhitung untuk melakukan aktivitas sehari-hari dalam kehidupan keluarga dan bermasyarakat.

Kurikulum yang digunakan berbasis pada konteks lokal, desain lokal, partisipatif, dan bermanfaat bagi peserta didik. Dengan jumlah jam pelajaran @ 60 menit adalah 114 jam pelajaran yang terdiri atas keterampilan membaca dan menulis 80 jam dan keterampilan berhitung sebanyak 34 jam dengan mengacu pada Peraturan Menteri Pendidikan dan Kebudayaan Republik Indonesia Nomor 86 Tahun 2014 tentang Penyelenggaraan Pendidikan Keaksaraan Dasar.

Kurikulum pendidikan keaksaraan dasar terdiri atas kompetensi inti dan kompetensi dasar yang mencakup ranah sikap, pengetahuan, dan keterampilan. Kompetensi inti 1 (sikap), yaitu menjalankan ibadah sesuai dengan kepercayaan masing-masing sehingga dapat berperilaku dan memiliki etika sebagai warga masyarakat yang baik. Kompetensi inti 2 (pengetahuan), yaitu 
menguasai pengetahuan faktual tentang cara mendengar, membaca, menulis, dan berbicara dalam bahasa Indonesia, serta berhitung untuk menyelesaikan masalah sehari-hari. Kompetensi inti 3 (keterampilan), yaitu mampu membaca, menulis, dan berhitung untuk mendukung aktivitas di lingkungan keluarga dan masyarakat dalam kehidupan sehari-hari (Permendikbud Nomor 86 Tahun 2014).

Tabel 1

Kompetensi Inti (KI) dan Kompetensi Dasar (KD)

\begin{tabular}{|c|c|c|c|}
\hline No. & Kompetensi Inti & & Kompetensi Dasar \\
\hline \multirow[t]{3}{*}{1} & Dimensi sikap & 1 & $\begin{array}{l}\text { Mampu melakukan ibadah } \\
\text { sesuai dengan agama dan } \\
\text { kepercayaan masing-masing }\end{array}$ \\
\hline & & 2 & $\begin{array}{l}\text { Mampu menunjukkan sikap } \\
\text { santun dalam berkomunikasi dan } \\
\text { taat pada aturan yang disepakati }\end{array}$ \\
\hline & & 3 & $\begin{array}{l}\text { Mampu menunjukkan sikap jujur } \\
\text { dalam berkomunikasi dan berhi- } \\
\text { tung pada kehidupan sehari-hari }\end{array}$ \\
\hline
\end{tabular}

2 Dimensi penge- 1 Menguasai teknik membaca tahuan

2 Mengenal teks personal tentang identitas diri

3 Mengenal teks deskripsi mi-nimal tiga kalimat sederhana yang berkaitan dengan kehidupan sehari-hari

4 Mengenal teks informal sederhana dalam bentuk poster yang berkaitan dengan kehidupan sehari hari

5 Mengenal teks narasi pendek minimal tiga kalimat sederhana yang berkaitan dengan kehidupan sehari-hari

6 Mengenal teks petunjuk/ arahan minimal tiga kalimat sederhana yang berkaitan dengan kehidupan sehari-hari

7 Mengenal bilangan (11000), uang, dan operasinya dalam kehidupan sehari-hari

8 Mengenal dan membaca satuan panjang, berat, isi, dan waktu yang biasa digunakan dalam kehidupan sehari-hari

Dimensi keter- 1 Membaca suku kata yang ampilan terdiri atas huruf vokal dan konsonan berkaitan dengan kehidupan sehari-hari

2 Membaca lancar teks minimal tiga kalimat sederhana dan memahami isinya

3 Menulis kata dan kalimat sederhana yang berkaitan denga kehidupan sehari-hari

4 Menulis teks personal tentang identitas diri

\begin{tabular}{|c|c|c|c|}
\hline \multirow[t]{8}{*}{ No. } & \multirow{2}{*}{\multicolumn{2}{|c|}{ Kompetensi Inti }} & Kompetensi Dasar \\
\hline & & & $\begin{array}{l}\text { Menulis teks deskripsi ten- } \\
\text { tang penggambaran sebuah } \\
\text { objek (benda, hewan, tumbu- } \\
\text { han, atau orang) dalam ba- } \\
\text { hasa Indonesia minimal tiga } \\
\text { kalimat sederhana berkaitan } \\
\text { dengan kehidupan sehari-hari }\end{array}$ \\
\hline & & 6 & $\begin{array}{l}\text { Menulis teks informasi } \\
\text { dalam bentuk poster meng- } \\
\text { gunakan bahasa Indonesia }\end{array}$ \\
\hline & & 7 & $\begin{array}{l}\text { Menulis teks narasi minimal } \\
\text { tiga kalimat yang di dalam- } \\
\text { nya terdapat kalimat ma- } \\
\text { jemuk berdasarkan gambar } \\
\text { tunggal atau gambar seri }\end{array}$ \\
\hline & & 8 & $\begin{array}{l}\text { Menulis teks petunjuk/arahan } \\
\text { tentang kehidupan sehari-hari } \\
\text { minimal tiga kalimat dengan } \\
\text { atau tanpa bantuan gambar }\end{array}$ \\
\hline & & 9 & $\begin{array}{l}\text { Melakukan dan menggunakan } \\
\text { operasi penjumlahan, pengura- } \\
\text { ngan, perkalian, dan pembagian } \\
\text { bilangan sampai dua angka } \\
\text { dalam kehidupan sehari-hari }\end{array}$ \\
\hline & & 10 & $\begin{array}{l}\text { Memperkirakan atau mem- } \\
\text { bulatkan hasil perhitungan } \\
\text { dalam kehidupan sehari-hari }\end{array}$ \\
\hline & & 11 & $\begin{array}{l}\text { Mengukur dan menggunak- } \\
\text { an satuan ukuran panjang, } \\
\text { jarak, berat, dan waktu yang } \\
\text { biasa digunakan dalam ke- } \\
\text { hidupan sehari-hari serta } \\
\text { menafsirkan hasil pengukuran }\end{array}$ \\
\hline
\end{tabular}

Identifikasi struktur tema dan materi mengacu pada kurikulum program pendidikan keaksaraan dasar maupun potensi dan permasalahan lokal yang ada pada masyarakat KAT suku Dayak Meratus, terutama di Kabupaten Hulu Sungai Selatan. Ruang lingkup bahan ajar dalam program pendidikan KDKAT meliputi tema ekonomi, kesehatan dan siklus hidup, serta ritual.

Standar kompetensi dan kompetensi dasar yang telah diuraikan di atas dapat dilihat secara rinci pada tabel 2 .

Tabel 2

Struktur Tema Bahan Ajar Seni dan Budaya

\begin{tabular}{lclc}
\hline \multicolumn{1}{c}{ Sub Tema } & & Kompetensi Dasar & $\begin{array}{c}\text { Jam } \\
\text { Pel }\end{array}$ \\
\hline $\begin{array}{l}\text { Ekonomi/ } \\
\text { pekerjaan/ } \\
\text { profesi }\end{array}$ & 2.1 & Menguasai teknik membaca & 48 \\
& 3.1 & $\begin{array}{l}\text { Membaca suku kata dan kata } \\
\text { yang terdiri atas huruf vokal } \\
\text { dan konsonan berkaitan dengan } \\
\end{array}$ & $\begin{array}{l}\text { kehidupan sehari-hari } \\
\text { Mengenal bilangan (1-1000), }\end{array}$ \\
& 2.7 & $\begin{array}{l}\text { Mang, dan ope-rasinya dalam } \\
\text { kehidupan sehari-hari }\end{array}$ \\
\hline
\end{tabular}




\begin{tabular}{|c|c|c|c|}
\hline Sub Tema & & Kompetensi Dasar & $\begin{array}{l}\text { Jam } \\
\text { Pel }\end{array}$ \\
\hline & 3.9 & $\begin{array}{l}\text { Melakukan dan menggunakan } \\
\text { operasi penjumlahan, penguran- } \\
\text { gan, perkalian, dan pembagian } \\
\text { bilangan sampai dua angka } \\
\text { dalam kehidupan sehari- hari }\end{array}$ & \\
\hline & 3.10 & $\begin{array}{l}\text { Memperkirakan atau membu- } \\
\text { latkan hasil perhitungan dalam } \\
\text { kehidupan sehari-hari }\end{array}$ & \\
\hline & 2.8 & $\begin{array}{l}\text { Mengenal dan membaca satuan } \\
\text { panjang, berat, isi, dan waktu } \\
\text { yang biasa digunakan dalam } \\
\text { kehidupan sehari-hari }\end{array}$ & \\
\hline & 3.11 & $\begin{array}{l}\text { Mengukur dan mengguna-kan } \\
\text { satuan ukuran panjang, jarak, } \\
\text { berat, dan waktu yang biasa } \\
\text { digunakan dalam kehidupan } \\
\text { sehari-hari serta menafsirkan } \\
\text { hasil pengukuran }\end{array}$ & \\
\hline \multirow[t]{11}{*}{ Kesehatan } & 2.7 & $\begin{array}{l}\text { Mengenal bilangan (1-1000), } \\
\text { uang, dan ope-rasinya dalam } \\
\text { kehidupan sehari-hari }\end{array}$ & 44 \\
\hline & 3.9 & $\begin{array}{l}\text { Melakukan dan menggunakan } \\
\text { operasi penjumlahan, penguran- } \\
\text { gan, perkalian, dan pembagian } \\
\text { bilangan sampai dua angka } \\
\text { dalam kehidupan sehari- hari }\end{array}$ & \\
\hline & 3.10 & $\begin{array}{l}\text { Memperkirakan atau membu- } \\
\text { latkan hasil perhitungan dalam } \\
\text { kehidupan sehari-hari }\end{array}$ & \\
\hline & 2.8 & $\begin{array}{l}\text { Mengenal dan membaca satuan } \\
\text { panjang, berat, isi, dan waktu } \\
\text { yang biasa digunakan dalam } \\
\text { kehidupan sehari-hari }\end{array}$ & \\
\hline & 3.11 & $\begin{array}{l}\text { Mengukur dan mengguna-kan } \\
\text { satuan ukuran panjang, jarak, } \\
\text { berat, dan waktu yang biasa } \\
\text { digunakan dalam kehidupan } \\
\text { sehari-hari serta menafsirkan } \\
\text { hasil pengukuran }\end{array}$ & \\
\hline & 3.2 & $\begin{array}{l}\text { Membaca lancar teks minimal } \\
\text { tiga kalimat sederhana dan } \\
\text { memahami isinya }\end{array}$ & \\
\hline & 3.3 & $\begin{array}{l}\text { Menulis kata dan kalimat seder- } \\
\text { hana yang berkaitan dengan } \\
\text { kehidupan sehari-hari }\end{array}$ & \\
\hline & 2.4 & $\begin{array}{l}\text { Mengenal teks informasi seder- } \\
\text { hana dalam bentuk poster yang } \\
\text { berkaitan de-ngan kehidupan } \\
\text { sehari-hari }\end{array}$ & \\
\hline & 3.6 & $\begin{array}{l}\text { Menulis teks informasi dalam } \\
\text { bentuk poster menggunakan } \\
\text { bahasa Indonesia }\end{array}$ & \\
\hline & 2.5 & $\begin{array}{l}\text { Mengenal teks narasi pendek } \\
\text { minimal tiga kalimat sederhana } \\
\text { yang berkaitan dengan kehidu- } \\
\text { pan sehari-hari }\end{array}$ & \\
\hline & 3.7 & $\begin{array}{l}\text { Menulis teks narasi minimal } \\
\text { tiga kalimat yang di dalamnya } \\
\text { terdapat kalimat majemuk ber- } \\
\text { dasarkan gambar tunggal atau } \\
\text { gambar seri }\end{array}$ & \\
\hline Siklus hidup & 2.2 & $\begin{array}{l}\text { Mengenal teks personal tentang } \\
\text { identitas diri }\end{array}$ & 22 \\
\hline
\end{tabular}

\begin{tabular}{|c|c|c|c|}
\hline Sub Tema & & Kompetensi Dasar & $\begin{array}{l}\text { Jam } \\
\text { Pel }\end{array}$ \\
\hline & 3.4 & $\begin{array}{l}\text { Menulis teks personal tentang } \\
\text { identitas diri }\end{array}$ & \\
\hline & 2.3 & $\begin{array}{l}\text { Mengenal teks deskripsi ten- } \\
\text { tang penggambaran sebuah } \\
\text { objek (benda, hewan, tumbuhan, } \\
\text { atau orang) minimal dalam tiga } \\
\text { kalimat yang berkaitan dengan } \\
\text { kehidupan sehari-hari }\end{array}$ & \\
\hline & 3.5 & $\begin{array}{l}\text { Menulis teks deskripsi tentang } \\
\text { penggambaran sebuah ob- } \\
\text { jek dalam bahasa Indonesia } \\
\text { minimal tiga kalimat sederhana } \\
\text { berkaitan de-ngan kehidupan } \\
\text { sehari-hari }\end{array}$ & \\
\hline & 2.6 & $\begin{array}{l}\text { Mengenal teks petunjuk/ ara- } \\
\text { han minimal tiga kalimat yang } \\
\text { berkaitan dengan kehidupan } \\
\text { sehari-hari }\end{array}$ & \\
\hline & 3.8 & $\begin{array}{l}\text { Menulis teks petunjuk/ arahan } \\
\text { tentang kehidupan sehari-hari } \\
\text { minimal tiga kalimat dengan atau } \\
\text { tanpa bantuan gambar }\end{array}$ & \\
\hline
\end{tabular}

Dari struktur kurikulum tersebut dikembangkan bahan ajar yang didesain berkonteks lokal suku Dayak Meratus dengan menggunakan dua bahasa yaitu bahasa Indonesia dan bahasa Dayak Meratus. Bahan ajar disusun dalam tiga seri yaitu (1) seri pekerjaan, (2) seri kesehatan, dan (3) seri siklus hidup.

Uji validitas konseptual produk bahan ajar pendidikan KD-KAT diperoleh dengan perhitungan rata-rata (mean) dalam bentuk persentase. Hasil perhitungan tingkat validitas model konseptual diperoleh $82,8 \%$ yang berarti tingkat validitas sangat tinggi. Uji kemenarikan dan keterbacaan konseptual diperoleh dengan perhitungan rata-rata (mean) dan diperoleh hasil $76,4 \%$ yang berarti tingkat kemenarikan model dalam kategori tinggi. Bahan ajar diterapkan pada dua kelompok sasaran pada wilayah yang berbeda, namun memiliki karakteristik yang sama yaitu menggunakan bahasa sehari-hari yang sama bahasa Dayak Meratus, dan memiliki kondisi lingkungan dan permasalahan yang sama yaitu masyarakat pegunungan Meratus yang mata pencaharian tergantung pada perkebunan dan sumberdaya alam pegunungan Meratus.

Penerapan bahan ajar diawali dengan kegiatan pretest atau penilaian awal dan dilanjutkan dengan kegiatan pembelajaran serta diakhiri dengan ujian dengan soal yang sama antara kedua kelompok. Aksi dalam kegiatan pembelajaran 
keaksaraan dasar berupa praktik membaca, menulis, dan berhitung yang sesuai dengan kegiatan hidup mereka sehari-hari, yaitu menjual hasil sumber daya alam pegunungan Meratus. Perancangan kegiatan atau aksi dalam pembelajaran melibatkan peserta didik berdasarkan minat dan kebutuhan peserta didik dengan memanfaatkan potensi setempat yang ada.

\section{Analisis kelas/uji normalitas}

Menggunakan uji normalitas kormogorov smirnov, dengan membandingkan distribusi data yang akan diuji normalitasnya. Distribusi data tes diperoleh signifikan di atas 0,05 berarti data yang diuji normal.

\section{Uji efektifitas produk}

Dilakukan melalui uji t paired two sample for means. Uji ini digunakan untuk membandingkan selisih dua mean dari dua sampel berpasangan dengan asumsi distribusi normal. Menurut hipotesis dalam uji t paired sample test, jika sig. $<0,05$ berarti ada perbedaan. Dari uji t paired two sample for means, hasil signifikan 0,000. Berarti angka signifikan kurang dari 0,05. Hasil tersebut menunjukkan ada perbedaan antara kedua kelas yang diuji.

Dilanjutkan dengan uji t independent t-test, diperoleh hasil 0,033 $(\leq 0,05)$ yang berarti ada perbedaan yang signifikan antara kelompok eksperimen yang pembelajarannya menggunakan bahan ajar hasil pengembangan dengan kelompok kontrol sehingga bahan ajar pendidikan keaksaraan dasar yang digunakan dalam pembelajaran berpengaruh terhadap efektivitas keberhasilan pembelajaran pendidikan keaksaraan dasar pada KAT suku Dayak Meratus.

\section{Pembahasan}

Pendidikan keaksaraan dasar pada KAT adalah layanan pendidikan pada warga masyarakat buta aksara latin dan bahasa Indonesia agar memiliki kemampuan membaca, menulis dan berhitung, berbahasa Indonesia, dan menganalisis sehingga memberikan peluang untuk aktualisasi potensi diri pada masyarakat di sekitarnya. Sesuai dengan Permendikbud No 86 Tahun 2014 tentang Pedoman Penyelenggaraan Pendidikan Keaksaraan Dasar, dijelaskan bahwa desain pembelajaran sebaiknya berkonteks lokal. Pembelajaran yang berkonteks lokal akan memudahkan peserta didik dalam memahami materi dalam rangka mencapai standar kompetensi yang diprasyaratkan, karena materi belajar berhubungan dengan kehidupan dan kebiasaan mereka sehari-hari.
Guna mendukung terlaksananya program pendidikan KD-KAT, maka perlu adanya kelengkapan sarana pembelajaran berupa bahan ajar, silabus dan RPP, panduan pembelajaran, dan panduan penilaian yang didesain berkonteks lokal sehingga dapat memberikan kemudahan bagi para penyelenggara dan pendidik program pendidikan KD-KAT. Pembahasan hasil kajian pembelajaran pendidikan KD-KAT suku Dayak Meratus difokuskan pada (1) produk pengembangan, bahan ajar, silabus dan RPP, panduan pembelajaran, dan panduan penilaian; (2) penggunaan produk bahan ajar, silabus dan RPP, panduan pembelajaran, dan panduan penilaian dalam pembelajaran, serta (3) efektivitas produk.

Produk pengembangan yang dihasilkan dalam penelitian pengembangan ini berupa perangkat pembelajaran yang terdiri dari bahan ajar, silabus dan RPP, panduan pembelajaran, dan panduan penilaian pendidikan keaksaraan dasar pada komunitas adat terpencil suku Dayak Meratus. Perangkat pembelajaran yang didesain konteks lokal dengan mengunakan pendekatan bahasa ibu, yaitu dalam bahasa Dayak Meratus dan bahasa Indonesia dengan materi pembelajaran dari kehidupan seharihari di kelompok sasaran komunitas suku Dayak Meratus, khususnya di Kabupaten Hulu Sungai Selatan dan Kabupaten Balangan.

Berdasarkan Permendikbud No. 86 Tahun 2014, silabus yang dikembangkan sesuai dengan struktur kurikulum yang dikembangkan yaitu diperuntukan 114 jam pelajaran @60 menit yang terdiri dari keterampilan membaca dan menulis sebanyak 80 jam dan keterampilan berhitung sebanyak 34 jam. Materi disusun dalam 3 seri bahan ajar. Materi disajikan dengan strategi transliterasi yaitu disajikan dalam dua bahasa, meliputi (1) teks berwarna merah menggunakan bahasa Dayak Meratus, yaitu bahasa asli masyarakat Dayak pada pegunungan Meratus Kabupaten Hulu Sungai Selatan; dan (2) teks berwarna hitam menggunakan bahasa Indonesia, sesuai dengan standar kompetensi lulusan yaitu bisa berkomunikasi dalam bahasa Indonesia. Penggunaan produk dalam pembelajaran dipermudah dengan adanya panduan dalam melaksanakan kegiatan pembelajaran di masing-masing perangkat pembelajaran yang disusun.

\section{Respon pengelola dan pendidik}

Perangkat pembelajaran yang disusun memberikan kemudahan bagi pengelola maupun 
tutor pendidikan KD-KAT dalam menyusun RPP, melaksanakan kegiatan belajar dan pembelajaran maupun melakukan penilaian hasil belajar peserta didik. Penggunaan bahan ajar dapat dilakukan dalam pembelajaran baik tatap muka, tutorial dan pendampingan. Karena keterbatasan penyusunan bahan ajar, maka dalam pembelajaran materi dapat berkembang atau bertambah dari hasil pembelajaran dengan strategi belajar, yaitu Belajar dari Pengalaman Sendiri (BDPS).

Respon peserta didik dapat diketahui dari wawancara dan pengamatan, dengan adanya bahan ajar maka peserta didik juga dapat membaca dan mengulang kembali materi pembelajaran di rumah. Pengulangan dapat dilakukan bersama pendidik maupun orang lain (yang dikenal dengan sebutan tutor sebaya). Peserta didik dapat memanfaatkan materi dalam bahan ajar untuk meningkatkan kualitas kehidupan sehari-hari.

\section{Efektivitas produk dalam pembelajaran}

Efektivitas produk dalam pembelajaran diketahui dengan membandingkan selisih dua mean dari sampel kelas eksperimen dan kelas kontrol. Uji efektivitas ini mengunakan nilai hasil pretest dan posttest kedua kelompok. Berdasarkan hasil pengujian diperoleh angka signifikan 0,033 yang menurut hipotesis jika angka signifikan $<0,05$ sehingga hipotesis nol ditolak. Artinya terdapat perbedaan hasil belajar peserta didik yang menggunakan bahan ajar yang disusun pengembang dengan yang tidak menggunakan bahan ajar yang disusun pengembang. Hasil pengujian tersebut memberikan pengertian bahwa adanya produk penelitian pengembangan yang berupa perangkat pembelajaran yang digunakan dalam pembelajaran pendidikan keaksaraan dasar pada komunitas adat terpencil suku Dayak Meratus ada pengaruhnya terhadap pencapaian hasil belajar peserta didik.

Dengan pengujian tersebut maka perangkat pembelajaran pendidikan keaksaraan dasar pada komunitas adat terpencil suku Dayak Meratus berhasil dan berguna sebagai alat bantu bagi tutor untuk membelajarkan materi pendidikan keaksaraan dasar yang sesuai dengan kurikulum, dan sebagai alat bantu bagi peserta didik untuk menguasai materi pembelajaran yang disampaikan oleh tutor. Dengan demikian perangkat pembelajaran pendidikan keaksaraan dasar pada komunitas adat terpencil suku Dayak Meratus telah efektif meningkatkan hasil belajar peserta didik baik ranah sikap, pengetahuan maupun keterampilan.

Dampak lain pembelajaran pendidikan keaksaraan dasar pada komunitas adat terpencil suku Dayak Meratus yaitu adanya perubahan perilaku masyarakat, dalam hal ini adanya rasa percaya diri dalam berinteraksi sosial dengan lingkungan di antara sesama suku Dayak Meratus maupun di luar lingkungan suku Dayak Meratus.

\section{PENUTUP}

\section{Kesimpulan}

Pendidikan keaksaraan dasar pada komunitas adat terpencil adalah layanan pendidikan pada masyarakat buta aksara latin agar memiliki kemampuan membaca, menulis dan berhitung, berbahasa Indonesia, dan menganalisa sehingga memberikan peluang untuk aktualisasi potensi diri pada komunitas adat terpencil/khusus. Sesuai dengan Permendikbud No. 86 Tahun 2014 tentang Pedoman Penyelenggaraan Pendidikan Keaksaraan Dasar, dijelaskan bahwa desain pembelajaran sebaiknya berkonteks lokal. Pembelajaran yang berkonteks lokal akan memudahkan peserta didik memahami materi dalam rangka mencapai standar kompetensi yang diprasyaratkan.

Bahan ajar merupakan salah satu sarana dalam penyelenggaraan program pendidikan keaksaraan dasar. Bahan ajar yang sesuai dengan standar kurikulum akan menghantarkan peserta didik untuk mencapai standar kompetensi lulusan. Menyiapkan bahan ajar adalah tanggung jawab pendidik yang dianggap sulit. Oleh karena itu, dengan adanya pengembangan model ini diharapkan memudahkan pengelola dan tutor dalam menyelengarakan program pendidikan pada komunitas adat suku Dayak Meratus. Bahan yang dikembangkan didesain lokal dengan memanfaatkan potensi, budaya, permasalahan, dan kondisi lingkungan sekitar sasaran program yang ditulis dalam dua bahasa, yaitu bahasa Indonesia dan bahasa Dayak sehingga diharapkan memudahkan peserta didik memahami materi pembelajaran dan bisa memanfaatkan isi materi dalam aspek kehidupan sehari-hari. Bahan ajar ini disusun berdasarkan kearifan lokal dan budaya lokal komunitas adat khusus suku Dayak, sehingga pemakaian bahan 
ajar ini masih terbatas pada wilayah suku Dayak di Kalimantan selatan.

\section{Saran}

Penyelenggaraan pendidikan keaksaraan dasar komunitas adat terpencil suku Dayak Meratus memiliki satu kesulitan tersendiri, untuk mengatasi kesulitan tersebut upaya yang dapat dilakukan diantaranya pertama, penyiapan perangkat pembelajaran seperti bahan ajar, silabus dan RPP yang berkonteks lokal akan memudahkan pengelola dan tutor dalam menyelengarakan program pendidikan KD-KAT khususnya pada suku Dayak Meratus. Kedua, menyiapkan bahan ajar yang sesuai dengan konteks lokal untuk memudahkan tutor dalam membelajarkan isi suatu program. Bahan ajar yang berkonteks lokal dan sesuai dengan standar kurikulum akan menghantarkan peserta didik untuk mencapai standar kompetensi lulusan. Ketiga, pembuat kebijakan memfasilitasi kegiatan pengembangan perangkat pembelajaran bagi KAT suku Dayak Meratus.

\section{DAFTAR PUSTAKA}

Arsyad, A. (2003). Media pembelajaran. Jakarta: Raja Grafindo.

Badan Pusat Statistik. (2016). Survei sosial ekonomi nasional tahun 2016. Diakses dari https:// microdata.bps.go.id/mikrodata/index.php/ catalog/SUSENAS

Borg, W. R., \& Gall, M.D. (1979). Educational research, an Introduction 3 ed. New York: Longman.

Dinas Kependudukan dan Catatan Sipil Kabupaten Hulu Sungai Selatan. (2013). Data kependudukan. Diakses dari http://dukcatpil. hulusungaiselatankab.go.id/

Dinas Pendidikan Kabupaten Balangan. (2017). Data buta aksara tahun 2017. Diakses dari http:// www.balangankab.go.id/?set=viewBk\&flag_te mplate $2=1$ \&lag $=1$ \&page $=1 \& \mathrm{id}=473$

Dinas Pendidikan Kabupaten Hulu Sungai Selatan. (2016). Data buta aksara tahun 2016. Diakses dari http://disdik.hulusungaiselatankab.go.id/

Ella, Y. (2016). Tahun 2030 seluruh anak peroleh akses pendidikan pra-SD. Diakses dari https:// www.kemdikbud.go.id/main/blog/2016/02/ tahun-2030-seluruh-anak-peroleh-akses-

\section{pendidikan-prasd}

Faidi, A. (2015). Suku dayak suku terbesar dan tertua di Kalimantan. Makassar: Arus Timur.

Kalimantan Pos. (2016). Sambutan Gubernur Kalimantan Selatan pada Hari Aksara Internasional tahun 2016. Diakses dari http://pauddikmaskalsel.kemdikbud.go.id/ index.php/berita-bp-paudni/496-upacaraperingatan-hari-aksara-internasional-provinsikalimantan-selatan

Peraturan Menteri Pendidikan dan Kebudayaan Republik Indonesia Nomor 86 tahun 2014 tentang Penyelenggaraan Pendidikan Keaksaraan Dasar

Peraturan Menteri Dalam Negeri Nomor 39 Tahun 2007 tentang Pedoman Fasilitasi Ormas Bidang Budaya, Keraton dan Lemadat

Subdit Pendidikan Keaksaraan. (2005). Bahan ajar keaksaraan. Jakarta: Direktorat Pendidikan Masyarakat.

Syahriansyah, dkk. (2011). Upacara adat dayak dan banjar Kalimantan Selatan. Banjarmasin: Antasari Press. 